\title{
THE EFFECT OF HYPERCHOLESTEROLEMIA ON CORTICAL BONE THICKNESS OF WISTAR RATS (Rattus norvegicus)
}

\author{
Auliya Dzaqiyatus Sofka ${ }^{1}$, Pudji Lestari², Gadis Meinar Sari ${ }^{3}$ \\ ${ }^{1}$ Medical Education Study Program, ${ }^{2}$ Department of Public Health, ${ }^{3}$ Department of Physiology, Faculty of Medicine, \\ Universitas Airlangga, Surabaya, Indonesia
}

\section{ABSTRACT}

There have been several studies reporting the effect of hypercholesterolemia on cortical thickness, but it remains a controversy. Some studies suggest that hypercholesterolemia can decrease osteoblast activity and increase osteoclast activity. Meanwhile other studies suggest that hypercholesterolemia is a protective factor of osteoporosis. Therefore, it is necessary to conduct a study to determine the effect of hypercholesterolemia on cortical bone thickness. Method: This study used 8 rats (Rattus norvegicus) that were divided into 2 groups, including control group (KO) that was given standard diet and experimental group (K1) that was given high fat diet for 28 days and all were executed to obtain the femur bone. The cortical bone thickness was measured by using Optilab Viewer and Optilab Image Raster software. Result: The data analysis was conducted using independent $t$-test. A p value of <0.05 is considered significant. The results showed that hypercholesterolemia had significant effect on cortical bone thickness. The average cortical bone thickness in the control group was $146.92 \mu \mathrm{m}$ whereas in the experimental group was $124.53 \mu \mathrm{m}$, the mean difference between the two groups was $22.39 \mu \mathrm{m}$. There was a $6 \%$ decrease of cortical bone thickness. In conclusion, hypercholesterolemia can decrease cortical bone thickness of wistar rats (Rattus norvegicus).

Keywords: Hypercholesterolemia, cortical bone thickness

\section{ABSTRAK}

Penelitian tentang hiperkolesterolemia pada ketebalan tulang kortikal telah banyak dilaporkan, tetapi masih menjadi kontroversi. Beberapa penelitian menunjukkan bahwa hiperkolesterolemia dapat menurunkan aktivitas osteoblas dan meningkatkan aktivitas osteoklas. Sementara penelitian lain menunjukkan bahwa hiperkolesterolemia adalah faktor pelindung terhadap osteoporosis. Oleh karena itu perlu dilakukan penelitian tentang efek hiperkolesterolemia pada ketebalan tulang kortikal. Penelitian ini menggunakan 8 tikus (Rattus norvegicus) yang dibagi menjadi 2 kelompok, yaitu kelompok kontrol (KO) yang diberi diet standar dan kelompok eksperimen (K1) yang diberi diet tinggi lemak selama 28 hari dan semuanya dikorbankan untuk pemeriksaan tulang femur. Pengukuran ketebalan tulang kortikal femur menggunakan perangkat lunak Optilab Viewer dan Optilab Image Raster. Analisis data dilakukan dengan menggunakan independent t-test dengan signifikansi $p<0,05$. Hasil penelitian menunjukkan bahwa hiperkolesterolemia memiliki pengaruh signifikan terhadap ketebalan tulang kortikal. Ketebalan tulang kortikal rata-rata pada kelompok kontrol adalah 146,92 $\mu \mathrm{m}$ sedangkan pada kelompok eksperimen adalah 124,53 $\mu \mathrm{m}$, perbedaan rata-rata antara kedua kelompok adalah 22,39 $\mu \mathrm{m}$. Terdapat penurunan $6 \%$ ketebalan tulang kortikal. Kesimpulan penelitian ini adalah hiperkolesterolemia dapat menurunkan ketebalan tulang kortikal tikus wistar (Rattus norvegicus).

Kata kunci: Hiperkolesterolemia, ketebalan tulang kortikal

Corespondence: Gadis Meinar Sari, Jl. Mayjen. Prof. Dr. Moestopo No. 47, Surabaya 60132, Indonesia, Phone: (031) 5023621, Fax. (031) 5022472. E-mail: gadis-m-s@ @k.unair.ac.id

pISSN:2355-8393 • eISSN: 2599-056x • doi: http://dx.doi.org/10.20473/fmi.v55i1.12561

• Fol Med Indones. 2019;55:63-67 • Received 30 Jan 2019 • Accepted 6 Mar 2019

- Open access under CC-BY-NC-SA license • Available at https://e-journal.unair.ac.id/FMI/

\section{INTRODUCTION}

Hypercholesterolemia is defined as high plasma cholesterol level exceeding the normal range for healthy population. Total cholesterol level in adults is considered high if it reaches $240 \mathrm{mg} / \mathrm{dL}$ or above. Meanwhile, as for children and adolescents, the normal cut-off value for total cholesterol level is $200 \mathrm{mg} / \mathrm{dL}$
(Rantung et al 2014). Hypercholesterolemia is also characterized by an increase in total cholesterol level, low density lipoprotein (LDL) cholesterol, and triglycerides as well as a decrease in High Density Lipoprotein (HDL) cholesterol (Murray et al 2014). Elevation in blood cholesterol levels is associated with decrease bone thickness and increase risk of bone fractures (Cao 2011). 
An increasing percentage of fat mass in the body occurs on people who suffer from hypercholesterolemia. The percentage of body fat is positively related with osteopenia and non-spine fractures. Proinflammatory cytokines are able to stimulate osteoclast activity through activation of RANKL/RANK/OPG pathway (Pfeilschifter et al 2002). Besides, according to other studies, high cholesterol level can induce cathepsin $\mathrm{K}$ which directly increases RANKL production that subsequently binds to RANK receptor on the surface osteoclasts. Osteoclast activation induces osteoclastogenesis process which increases osteoclast production (Mandal 2015).

Another study explains that leptin clearly increases cell proliferation through the Saos2 cell pathway mediated by PI(3)K. Leptin also activates MAPK (Mitogen Activated Protein Kinase) which also mediates the Saos 2 cell pathway leading to increase cell proliferation. Leptin has a significant peripheral effect on bone mass. Leptin and its receptors are expressed in osteoblast cells and persistent leptin exposure could increase collagen synthesis, mineralization and osteoblast cell differentiation (Burguerra et al 2006).

From the background described above, the relationship between hypercholesterolemia and bone thickness remains unclear. Hence, the author intended to investigate the effects of hypercholesterolemia on bone metabolism, especially its impact on the reduction of bone density resulted from increased bone resorption by osteoclasts. In general, bone density measurement was conducted using densitometry apparatus and biochemical test; however, in this study the author was interested in measuring bone density from the cortical part of the bone. Measuring the width of the cortex which has high sensitivity and specificity in detecting osteoporosis can also be applied for measuring bone thickness (Alvarez et al 1997).

\section{MATERIALS AND METHODS}

In hypercholesterolemia, there is an increase in osteoclast activity, suppression of osteoblast activity, and reduction in bone remodelling among experimental rats with hyperlipidaemia (Krieger 1998). One study Luegmayr et al (2004) found that elevating plasma cholesterol levels induces imbalance in bone remodelling process and reduction of bone mass by increasing the activity and differentiation of osteoclast. Numerous previous studies concluded that hypercholesterolemia affects bone structure through various mechanisms. One of the consequences of hypercholesterolemia is reduction in bone thickness. A study Majima et al (2008) proved that patients with hypercholesterolemia have increase bone-specific alkaline phosphatase (BAP) and N-terminal telopeptide of type 1 collagen (Ntx) which are two of many markers for bone resorption. In addition, an animal study have shown that hypercholesterolemia increases osteoclast activity and reduces bone thickness in mice model (Majima et al 2008, Krieger 1998).

This study used 8 wistar rats (Rattus norvegicus) which were divided into 2 groups, including control group (K0) that was given standard diet and experimental group (K1) that was given high fat diet. According to Basso and Heersche (2006) execution and bone removal was done after 28 days of high cholesterol diet for experimental group and anytime for the control group. A study conducted by Gani et al (2013) showed that the cortical bone is removed from the muscle and other soft tissues around the bone, fixated for 72 hours in $4 \%$ of paraformaldehyde and decalcified for approximately 1 week using Na-Citrate. After decalcification, the specimen is embedded in paraffin and several transverse slices are made for each bone with $5 \mu \mathrm{m}$ thickness. Staining of the preparation was performed using hematoxylin-eosin (HE) stain (Gani et al 2013).

Each transverse slice was evaluated microscopically. The length of the periosteal and endosteal surfaces of at least 10 bone axes were measured using Optilab Viewer and Optilab Image Raster software in the histology laboratory of Faculty of Medicine Airlangga University. The mean length of periosteal and endosteal surfaces is presented to represent the cortical bone thickness.

Data were tabulated and descriptive analysis was conducted. After normality (Kolmogorov-smirnov test) and homogeneity (Levene's test) tests, parametric or non-parametric test was performed. Independent t-test was used for a set of normally distributed and homogenous data.

\section{RESULTS}

Histopathology examination was performed to determine the cortical bone thickness in both groups by measuring the 10 axis points (Fig. 1) and (Fig. 2).

The mean cortical bone thickness for control group and experimental group are $146.92 \mu \mathrm{m}$ and $124.53 \mu \mathrm{m}$, respectively (Table 1 ). The mean difference between control group (K0) and experimental group (K1) is $22.39 \mu \mathrm{m}$. We found $6 \%$ reduction of the cortical bone thickness in experimental group compared to control group. The results of Levene's test and Kolmogorovsmirnov test showed that our data were homogeneous and had normal distribution. 

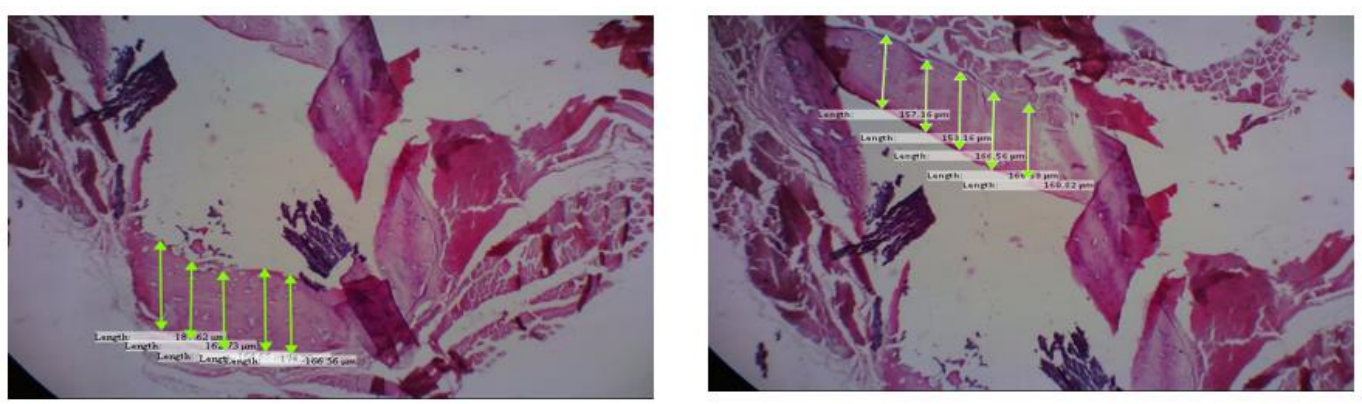

Fig. 1. Histological image of samples obtained from the control group (K0) (40x magnitude).
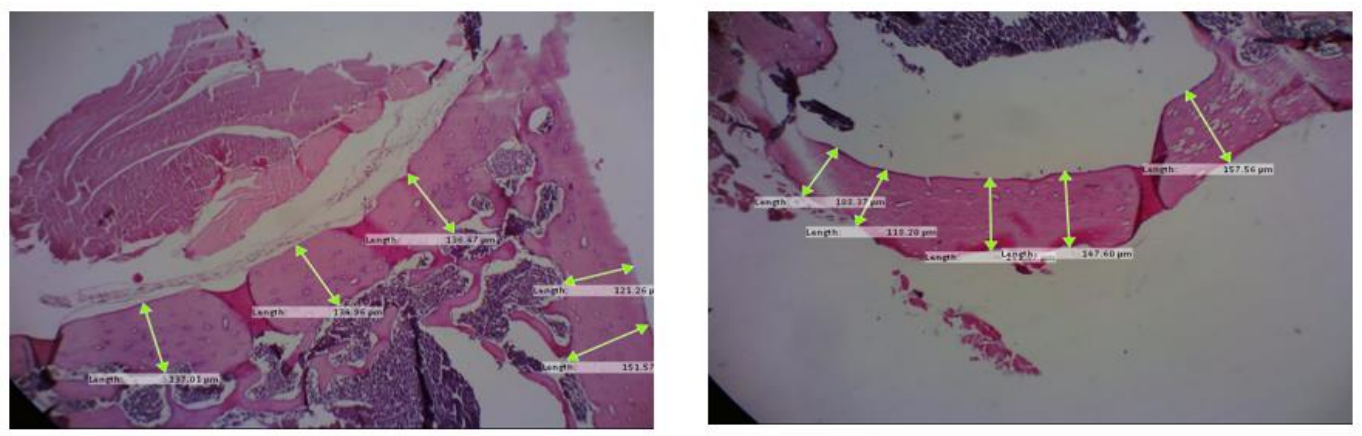

Fig. 2. Histological image of samples obtained from the experimental group (K1) (40x magnitude).

Table 1. Measurement of cortical bone thickness in control group (K0) and experimental group (K1)

\begin{tabular}{lcc}
\hline \multirow{2}{*}{ Sample } & \multicolumn{2}{c}{ Cortical Bone Thickness $(\mu \mathrm{m})$} \\
\cline { 2 - 3 } & Control Group $($ K0) & Experimental Group $(\mathrm{K} 1)$ \\
\hline 1 & 176.42 & 100.99 \\
2 & 140.02 & 142.12 \\
3 & 165.41 & 116.50 \\
4 & 159.38 & 138.50 \\
\hline Mean & 146.92 & 124.53 \\
\hline
\end{tabular}

Table 2. Analysis of cortical bone thickness in control group (K0) and hypercholesterolemia group (K1)

\begin{tabular}{lccc}
\hline & Control Group $(\mathrm{n}=4)$ & Experimental Group $(\mathrm{n}=4)$ & $\mathrm{p}$-value \\
\hline Cortical bone thickness & 146.92 & 124.53 & $<0.005$ \\
\hline Note: Independent t-test & & &
\end{tabular}

Therefore, independent t-test was employed to test for statistical significance. The cortical bone thickness in experimental group was significantly lower compared to the control group $(\mathrm{p}<0.005)$. The result was presented in Table 2.

\section{DISCUSSION}

Hypercholesterolemia reduces bone mass which causes osteoporosis. This works as warning that hypercholesterolemia can potentially harm bone health (Majima et al
2008). There is a theory showing that increased adipocyte cells in people who suffer from hypercholesterolemia can also increase leptin production. As a result, reduction of bone mass occurs due to brain stimulation that releases hypothalamic osteoblast inhibitory factor (HOBIF). Furthermore, the activation of $\mathrm{ObRb}$ (long leptin isoform receptor) in the hypothalamus stimulates HOBIF in which once secreted, it will decrease osteoblast activity to form the bone matrix. Another indirect mechanism for regulation of this substance is through activation Y2 receptors by 
neuropeptide Y (NPY) that stimulates HOBIF secretion (Siswo 2013).

Another study explains that leptin clearly increases cell proliferation through the Saos2 cell pathway that is mediated by PI (3) K. Leptin also activates MAPK (Mitogen Activated Protein Kinase) which also mediates the Saos2 cell pathway leading to increase cell proliferation. Leptin has significant peripheral effect on bone mass. Leptin and its receptor are expressed in the surface of osteoblast cells and long-term leptin exposure could increase collagen synthesis, mineralization and differentiation of osteoblast. This shows that mechanism on how leptin exerts its effects on bone metabolism remains to be elucidated. According to Burguerra et al (2006), several different pathways involved in these mechanisms lead to different results depending on the leptin dose.

On the other hand, hypercholesterolemia can induce cathepsin K of osteoclasts that are positively correlated with RANKL expression leading to increase osteoclastogenesis (Mandal 2015). Cathepsin K secreted by osteoclasts can resorb the bone and destruct the bone matrix which consists mostly of type 1 collagen (Now $\&$ Nandeesh 2012). RANKL stimulates osteoclastogenesis by binding RANK receptors on the surface of osteoclast precursors and mature osteoclast cells and directing the osteoclast precursors (macrophages/monocytes) to osteoclastogenesis (Chapter \& Sela 2012). Furthermore, according to a study conducted by Majima et al (2008), hypercholesterolemic patients have increased bone-specific alkaline phosphatase (BAP) and $\mathrm{N}$-terminal telopeptide of type I collagen ( $\mathrm{Ntx}$ ), which are two of many bone resorption markers. Moreover, the animal studies showed that hypercholesterolemia increases osteoclastic potential and reduces bone mass density in rats (Tintut et al 2003, Majima 2008).

According to Mandal (2015), high cholesterol diet given to experimental rats affects osteoblasts and osteoclast activities. As for osteoblast, reduction in BMP-2, ALP, Runx2, Collagen A1 results in decrease osteoblast cell proliferation whereas in osteoclasts, there is an increase in Tartate Resistant Acid Phospate (Trap) production, a bone resorption marker. This notion is also supported by a study stated that osteoblast activity is increased by statins (anti- cholesterol drugs). Furthermore, statins can inhibit osteoclast cell activity. Therefore, cholesterol reduction may inhibit osteoblasts apoptosis and increase osteoclasts apoptosis. The mechanism described above may be one of many mechanisms that cause reduction in bone density caused by hypercholesterolemia (Mandal 2015).

\section{CONCLUSION}

According to the results presented in this study on the effect of hypercholesterolemia on cortical bone thickness of Wistar rats (Rattus norvegicus), it can be concluded that mean cortical bone thickness in hypercholesterolemic Wistar rats was $124.53 \mu \mathrm{m}$. The study also found that cortical bone thickness of hypercholesterolemic wistar rats (Rattus norvegicus) is lower than those who have normal cholesterol level.

\section{REFERENCES}

Alvarez L, Peris P, Pons F, Guañabens N, Herranz R, Monegal A, Bedini J, Deulofeu R, De Osaba M, Munoz-Gómez J and Ballesta A (1997). Relationship between biochemical markers of bone turnover and bone scintigraphic indices in assessment of Paget's disease activity. Arthritis \& Rheumatism 40, 461-468

Basso N, Heersche J (2006). Effects of hind limb unloading and reloading on nitric oxide synthase expression and apoptosis of osteocytes and chondrocytes. Available from thebonejournal.com

Burguerra B, Brunetto A, Ocana A, Teijeiro R, Esplen J, Thomas $\mathrm{T}$ and Cource M (2006). Leptin increases proliferation of human osteosarcoma cells through activation of PI (3)-K and MAPK pathways. MedScitMonit, 12

Cao J (2011). Effects of obesity on bone metabolism. Journal of Orthopaedic Surgery and Research 6, 30

Chapter IA, Sela JJ (2012). Cellular and Molecular Aspects of Bone Repair in Sela, JJ \& Chapter, IA (eds). Principles of Bone Regeneration, p 1141

Gani N, Momuat L and Pitoi M (2013). Profile of plasma lipids wistar mice that hypercholesterolemia in red gedi giving (Abelmoschus manihot L.). JOURNAL OF MIPA UNSRAT ONLINE

Krieger M (1998). The "best" of cholesterols, the "worst" of cholesterols: A tale of two receptors. Proceedings of National Academy of Sciences of United States of America 95, 4077-4080

Luegmayr E, Glantschnig H, Wesolowski G, Gentile M, Fisher J, Rodan G and Reszka A (2004). Osteoclast formation, survival and morphology are highly dependent on exogenous cholesterol/lipoproteins. Cell Death and Differentiation 11, S108-S118

Majima T, Shimatsu A, Komatsu Y, Satoh N, Fukao A, Ninomiya K, Matsumura T and Nakao K (2008). Increased Bone Turnover in Patients with Hypercholesterolemia . J-STAGE

Mandal C (2015). High Cholesterol Deteriorates Bone Health: New Insights into Molecular Mechanisms. Frontiers in Endocrinology, 6

Murray RK, Granner DK, Rodwell VW (2014). Biokimia Harper 29th Ed. Jakarta, Penerbit Buku Kedokteran EGC, p 249 
Now U and Nandeesh BN (2012). Physiology of Bone Formation, Remodeling, and Metabolism in Fogelman, I., et al (eds). Radionuclide and Hybrid Bone Imaging, 29-57

Pfeilschifter J, Köditz R, Pfohl M and Schatz H (2002). Changes in Proinflammatory Cytokine Activity after Menopause. Endocrine Reviews , 23 (1), p 90-119
Rantung A, Umboh A and Mantik M (2014). Hubungan hiperkolesterolemia dengan obesitas pada siswa SMP Eben Haezar Manado. Journal E-Clinic (ECL)

Siswo L (2013). Obesity and bone loss, how to do? eprints.unsri

Tintut Y, Morony S, Demer L (2003). Hyperlipidemia Promotes Osteoclastic Potential of Bone Marrow Cells Ex Vivo. Arteriosclerosis, Thrombosis, and Vascular Biology 24, e6-e10 